\title{
Are computer skills the new basic skills? : the returns to computer, writing and math skills in Britain
}

Citation for published version (APA):

Borghans, L., \& ter Weel, B. J. (2003). Are computer skills the new basic skills? : the returns to computer, writing and math skills in Britain. Researchcentrum voor Onderwijs en Arbeidsmarkt, Faculteit der Economische Wetenschappen. ROA Research Memoranda No. 3E https://doi.org/10.26481/umaror.200303E

Document status and date:

Published: 01/01/2003

DOI:

10.26481/umaror.200303E

Document Version:

Publisher's PDF, also known as Version of record

\section{Please check the document version of this publication:}

- A submitted manuscript is the version of the article upon submission and before peer-review. There can be important differences between the submitted version and the official published version of record.

People interested in the research are advised to contact the author for the final version of the publication, or visit the DOI to the publisher's website.

- The final author version and the galley proof are versions of the publication after peer review.

- The final published version features the final layout of the paper including the volume, issue and page numbers.

Link to publication

\footnotetext{
General rights rights.

- You may freely distribute the URL identifying the publication in the public portal. please follow below link for the End User Agreement:

www.umlib.nl/taverne-license

Take down policy

If you believe that this document breaches copyright please contact us at:

repository@maastrichtuniversity.nl

providing details and we will investigate your claim.
}

Copyright and moral rights for the publications made accessible in the public portal are retained by the authors and/or other copyright owners and it is a condition of accessing publications that users recognise and abide by the legal requirements associated with these

- Users may download and print one copy of any publication from the public portal for the purpose of private study or research.

- You may not further distribute the material or use it for any profit-making activity or commercial gain

If the publication is distributed under the terms of Article $25 \mathrm{fa}$ of the Dutch Copyright Act, indicated by the "Taverne" license above, 
Are computer skills the new basic skills?

The returns to computer, writing and math skills in Britain*

ROA-RM-2003/3E

Lex Borghans, Bas ter Weel

* We would like to thank Eli Berman, Allard Bruinshoofd, Philip Marey, JörnSteffen Pischke, Gilles Saint-Paul for constructive criticism and helpful comments on an earlier draft of this paper. We also acknowledge SKOPE (University of Oxford) for providing the data. Our research is supported by grants from the Netherlands Organization for Scientific Research (NWO).

Research Centre for Education and the Labour Market

Faculty of Economics and Business Administration

Maastricht University

Maastricht, April 2003 
ISBN 90-5321-368-6

Sec03.037.doc 


\begin{abstract}
The large increase in computer use has raised the question whether people have to be taught computer skills before entering the labour market. Using data from the 1997 Skills Survey of the Employed British Workforce, we argue that neither the increase in computer use nor the fact that particularly higher skilled workers use a computer provides evidence that computer skills are valuable. We compare computer skills with writing and math skills and test whether wages vary with computer skills, given the specific use that is made of computers. The regression results show that while the ability to write documents and to carry out mathematical analyses yields significant labour-market returns, the ability to effectively use a computer has no substantial impact on wages. These estimates suggest that writing and math can be regarded as basic skills, but that the higher wages of computer users are unrelated to computer skills.
\end{abstract}

Keywords: Wage Differentials by Skill; Computer Use and Skill JEL Classification: J30; J31 


\section{Introduction}

During the last twenty years computer use at work has increased dramatically. In 1985 19.3 percent of the British workforce used a computer at work; in 1990 this percentage increased to 27.8 percent; in 1997 to 69.2 percent; and in 200173.7 percent of the workers used a computer. ${ }^{1}$ Since a major aim of the educational system is to prepare people for their working career, it is important to investigate whether the rapid diffusion of computers and its widespread, and still increasing, use should lead to more attention for teaching computer skills at school. In other words, are computer skills the new basic skills, just like the more traditional skills such as writing and math skills?

This paper investigates the labour-market returns to computer skills in comparison with the returns to writing and math skills in Britain using data from the 1997 Skills Survey of the Employed British Workforce. These data offer an opportunity to address the importance in the job, the level of sophistication and effectiveness of writing and math and computer use. The significance of the elaborate information about writing, math and computer use at work can be understood as follows. Computers, writing and math can be used in many different ways, which may be very important for certain jobs but less so for other occupations. The relationship between wages and the use of writing, math or computers at different levels of sophistication will therefore not only be influenced by the worker's skills, but also by the allocation of workers to jobs. Furthermore, more experience in jobs which require a great deal of writing, math or computer use will also increase the body of closely related skills. The

\footnotetext{
${ }^{1}$ See Borghans and Ter Weel (2002) for an overview of these figures of computer use at work and the data sources. Comparison of the numbers for the United Kingdom with the ones in Germany and the United States reveals that the level and pattern of computer use is similar in all three countries, although it seems to be fractionally higher in the United Kingdom than in the other two countries.
} 
direct relationship between these skills and wages therefore not only reveals the returns to the particular skill, but also the influence of the job allocation on wages. Hence, it is important to explicitly address the different ways in which writing, math and computers are used and to investigate whether within a certain kind, or at a particular level of sophistication, of use these skills are related to wages and yield labour-market returns.

Our findings can be summarized as follows. While writing documents and making calculations using advanced mathematical or statistical procedures have a significant positive impact on wages, computer skills do not seem to matter in a significant way for the wage. Only for the small group of workers who uses a computer for computer programming, a substantial positive but insignificant effect is found. The regression results suggest that the ability to use a computer effectively is not of great importance for a worker's performance in a job, implying that there is no evidence that computer skills are becoming a new basic skill important to teach at school. Rather, it seems to be the case for most jobs, that once computers have to be used, the necessary skills to do so are acquired relatively easily requiring little investments, if any.

The plan of this paper is the following. Section 2 presents the strategy of the analysis. Section 3 describes the data and the econometric specification. Section 4 reports the estimation results. Section 5 concludes and discusses the implications of the estimates.

\section{Strategy of the analysis}

Most empirical attempts to estimate the returns to computer skills are based on information about computer use, which is applied as a proxy for computer skills. The underlying assumption to do so is that workers who embody more skills will be allocated to 
jobs in which computer skills are required. This strategy only works when computer skills are indeed the only determinant in the allocation process. If this is not the case, which seems to be reasonable, the estimated returns to computer use will also include all wage differentials associated with other relevant factors in the allocation of workers to jobs.

As an alternative approach, one could estimate the relationship between wages and a direct measure of writing, math and computer skills. The main problem of this strategy is that if the use of writing, math or computers at work reveals characteristics of the worker that have nothing to do with the related skills, and if experience is increasing in use, a positive correlation between skills and wages might be a reflection of unobserved heterogeneity, rather than being a reflection of returns to skills. Even very trivial skills might turn out to have a return: If you know the room numbers of people in the board of McKinsey, you are probably working there, so your wage will be high.

The strategy in this paper to estimate the returns to skills is to investigate the relationship between skills and wages within a group of workers who use writing, math or computers at the same level of sophistication. ${ }^{2}$ In this way, we distinguish between workers using writing, math and computers for relatively simple tasks from workers carrying out relatively complex tasks, which is likely to have much more impact on their experience. For example, there is a large difference in using a computer for tasks such as printing out an invoice or for tasks such as programming and developing software. By the same token, writing long documents with a consistent line of thought will much more stimulate experience in this field than filling in standardized forms; and solving a dynamic optimization problem is likely to have a different impact on math skills than adding and subtracting numbers.

However, there might be differences among workers, which are not observed by the

\footnotetext{
${ }^{2}$ Section 3 provides details about the definitions of the levels of sophistication of these skills.
} 
econometrician. To illustrate the way in which an unobserved characteristic $x$ can influence the estimated returns to computer skills, consider the following three relationships:

$$
\begin{aligned}
& u=u(s, x), \\
& s=s(u, x)
\end{aligned}
$$

and

$$
w=w(s, x)
$$

Equation (1) shows that the allocation of workers to jobs in which computers are used at a level of sophistication $u$ depends on computers skills $s$ and unobserved characteristic $x$. Equation (2) expresses that computer skills $s$ might be related to this unobserved characteristic $x$, but that the allocation itself, e.g. through experience and on-the-job learning, will induce a higher level of computer skills. Equation (3) reveals that in a competitive labour market wages are determined by $s$ and $x$ but are not influenced by the allocation $u$.

Using these equations, we are able to show the effects of different approaches to estimating the returns to computer skills. First, several studies apply information about computer use, or the level of sophistication of computer use, as a proxy for computer skills (see footnote 4 in the next section for these studies). This yields biased estimates because estimating the derivative of the wage with respect to $u$ gives

$$
\frac{\mathrm{d} w}{\mathrm{~d} u}=\frac{\partial w}{\partial s} \frac{\partial s}{\partial u}+\frac{\partial w}{\partial x} \frac{\partial x}{\partial u}=\frac{1}{\frac{\partial u}{\partial s}} \frac{\partial w}{\partial s}+\frac{1}{\frac{\partial u}{\partial x}} \frac{\partial w}{\partial x} .
$$

Apart from an unknown scale factor $\partial s / \partial u$, representing the relationship between computer skills and computer use, the first term on the right hand side of equation (4) represents the returns to computer skills. The estimates of the relationship between computer skills and wages using only information about computer use is however likely to be seriously biased by the second term on the right hand side of equation (4), which expresses that there are other 
reasons than computer skills why people are allocated to jobs in which computers are used. These other determinants of the allocation of workers to jobs are in all likelihood correlated with wages.

It therefore seems more appropriate to use direct measures of computer skills to estimate its returns. Without controlling for the level of sophistication of computer use this yields

$$
\frac{\mathrm{d} w}{\mathrm{~d} s}=\frac{\partial w}{\partial s}+\frac{\partial w}{\partial x}\left[\frac{\partial x}{\partial s}+\frac{\partial x}{\partial u} \frac{\partial u}{\partial s}\right] .
$$

The second term on the right hand side of this expression shows that there exists a possible bias in this estimate, apart from the true returns to computer skills $(\partial w / \partial s)$. The first part of this term shows that the unobserved characteristic $x$ might be correlated with computer skills $s$. We do not consider this to be a serious problem for the estimation, since any skill that is closely related to computer skills will be correlated with computer skills. In practice, it is impossible to disentangle the returns to one specific skill by excluding the influence of, or correlation with, closely related skills to estimate the returns to this specific skill. We therefore interpret the measure of computer skills to represent also a set of very related skills. The second part of the bias is more problematic because it reveals that experience with using a computer increases skills. Of course, if computer skills yield labour-market returns, skills acquired by experience yield the same returns. The problem with this term is that computer use is related to unobserved characteristics, and therefore skills acquired by experience not only reveal the true value of computer skills, but are also associated with all wage differentials between computer users and non-users as a result of their unobserved characteristics. To reduce this bias we control for the level of sophistication of computer use in the regression equations, which means that de facto $\partial u / \partial s=0$. This implies that the last term on the right hand side of equation (5) is eliminated and does not bias the regression results. The estimation 
of this model yields information about the returns to skills not by solely comparing users and non-users, but also by comparing different workers using computers for similar purposes. Of course, the same arguments apply to the analysis of math and writing skills.

\section{Data and econometric specification}

The data utilized in this paper have been collected in a survey, conducted in the first half of 1997, called the Skills Survey of the Employed British Workforce. The survey includes a representative number of workers $(2,467)$ from Britain, aged 18-60. Participants were asked several dozens of questions on their labour-market situation during face-to-face interviews to obtain information on various aspects of their jobs including qualifications, responsibilities, the importance and ability to carry out certain tasks at work, and training. ${ }^{3}$

\subsection{Measurement}

Of interest for the purpose of our analysis are the detailed questions concerning the importance, level of sophistication, and effectiveness of writing, math and computer use. ${ }^{4}$

\footnotetext{
${ }^{3}$ See Ashton et al. (1999) for an elaborate discussion of the data and the survey methods used to collect the data.

${ }^{4}$ Particularly the information on computer use is unique. With respect to the level of sophistication of computer use, Entorf and Kramarz (1997) and Entorf et al. (1999) use the Enquête sur la Technique et l'Organisation du Travail auprès des Travailleurs Occupés, in which they distinguish three levels of computer use related to the autonomy of each worker. This is an indirect measure of the level of sophistication of computer use because it relates to the job in general, whereas the data used in this paper relate the level of sophistication of computer use to the worker's computerized tasks. The effectiveness of computer use has been measured indirectly as computer ability (Bell, 1996 for the United Kingdom) or computer knowledge (DiNardo and Pischke, 1996 for Germany and Hamilton, 1997 for the United States). These measures are related to computer ability or skills in a general sense, but do not necessarily reveal information about the effectiveness of conducting computerized job activities. The information on the effectiveness of computer use from the data analysed in this paper is directly related to the computerized tasks a worker has to perform. By measuring its effectiveness, a proxy for the worker's computer skills directly related to the job is obtained.
} 
With regard to the importance of writing, math and computer use the following question has been asked: "In your job, how important is ...?". The response scale offered is the following: “essential", "very important", "fairly important", "not very important", and "not at all important". We defined the dummy variables "pen use", "math use", and "computer use" to equal 1 for every worker who did not answer "not at all important".

With respect to the level of sophistication of writing and math, we distinguish three different levels. For writing we use information on the following three questions: "In your job how important is (i) writing material such as forms, notices or signs, (ii) writing short documents (for example, short reports, letters or memos), and (iii) writing long documents with correct spelling and grammar (for example, long reports, manuals, articles and books)?”. For the level of sophistication of the use of math at work we use information on the following three questions: "In your job how important is (i) adding, subtracting, multiplying or dividing numbers, (ii) calculations using decimals, percentages or fractions, and (iii) calculations using more advanced mathematical or statistical procedures?". Finally, the level of sophistication of computer use is addressed as follows: "Which of the following best describes your use of computers or computerized equipment in your job?". The answers are divided into four different levels of sophistication at which computers are being occupied. "Simple" use indicates "straightforward use, e.g., using a computer for straightforward routine procedures such as printing out an invoice in a shop"; "moderate" use means "e.g., using a computer for word processing and/or spreadsheets or communicating with others by email"; "complex" use is defined as "e.g., using a computer for analysing information of design, including use of computer-aided design or statistical analysis packages"; and, "advanced" use is described as “e.g., using a computer syntax and/or formulae for programming and developing software".

The effectiveness of, or skill in, writing, math and using a computer is measured by 
the answers to the following question: "When your job involves ..., are you able to do this effectively?". Five possible answers were offered: "always", "nearly always", "often”, "sometimes" and "hardly ever". We assigned a variable varying from 0 ("hardly ever") to 4 ("always") to each of these skills.

\subsection{Descriptive statistics}

Table 1 presents some descriptive statistics of the data. The first row shows that in 199786.1 percent of the British workers uses a pen at work, 82.3 percent is involved in activities where math use is required, and 69.2 percent of the workforce uses a computer.

The next three rows present information, at the different levels of sophistication, about the workers' answers to the effectiveness of writing, math and computer use, respectively. It turns out that workers have more difficulties with more advanced writing and mathematical job activities. The effectiveness of writing long documents and making use of advanced math are substantially lower than the effectiveness of relatively less advanced activities such as filling in forms and adding and subtracting numbers. Although people with more writing and math skills will be allocated to jobs with more skills requirements in this respect, it seems to be the case that the complexity of the writing and math tasks increases more than the skills of the workers carrying out these tasks. For computer use, the figures show an increasing level of

\footnotetext{
${ }^{5}$ Borghans and Ter Weel (2001) offer an elaborate discussion of the validity of this skill measure. For academic abilities and skills such as reading, writing and mathematics, it is possible to measure a respondent's skills by test items. This has the obvious advantage that for all respondents the skills are measured in an identical way. While the OECD will use this approach for numeracy and literacy skills in the forthcoming Life Skills Survey, computer skills seem to be too much context- or task-related to allow for a general set of test items (OECD, 2000). Spenner (1990) reports evidence from a number of studies finding high correlations between selfassessed measures of skill obtained by this and similar ways of questioning and measures obtained from objective judgements by experts and external expert systems used to develop the Dictionary of Occupational Titles.
} 
effectiveness when comparing the levels of sophistication at which computers are being used. Workers using a computer at the advanced level are more effective in doing so than people using a computer for relatively simple tasks. These figures suggests that the demand for people carrying out complex computer tasks is not limited by the supply of computer skills.

The final row of Table 1 provides information about a number of demographic variables. The average hourly wage in Pounds Sterling equals 7.43 . There are six educational categories in the data: (0) no diploma, (1) NVQ1, (2) NVQ2, (3) NVQ3, (4) NVQ4, and (5) University. The average educational level is just above the NVQ2 level (2.226). The average years of work experience equals about 19 years. 25.3 percent of the workforce is employed on a part-time basis, 47.1 percent of the sample is female, and 69.3 percent is married.

\subsection{Econometric specification}

In estimations putting forward the computer wage premium, the log of the gross hourly wage of individual $i\left(\ln W_{i}\right)$ is explained in an OLS-regression using a dummy for computer use $\left(c u_{i}\right)$ equalling 1 if individual $i$ uses a computer, and 0 otherwise, and a vector of other controls $\left(Z_{i}\right)$, i.e.

$$
\ln W_{i}=C+\alpha_{1} c u_{i}+Z_{i} \beta+\varepsilon_{i}
$$

where $\alpha_{1}$ and $\beta$ are the estimated parameters, $C$ is the constant term and $\varepsilon$ is an error term with the usual assumptions. Most studies estimating equation (6) find a substantial computer wage premium. ${ }^{6}$ This premium is often interpreted as a premium for computer skills (e.g., Krueger, 1993). DiNardo and Pischke (1997) however also estimate equation (6) by replacing computer

\footnotetext{
${ }^{6}$ The wage premium in such cross-sectional analyses varies between 10 and 25 percent.
} 
use by the use of pens and pencils and find a premium of similar size. In interpreting their findings, DiNardo and Pischke (1997) argue that one can expect everyone to be able to use a pen and that the effect of pens on wages is not the result from the ability to use a pen, but depends on the kind of use that is made of a pen, introducing a heterogeneity bias in the estimates. To get around this problem, as argued in the previous section, it is appropriate to estimate a wage equation in which the different levels of sophistication of writing, math and computer use are applied:

$$
\ln W_{i}=C+\alpha_{1} u_{i}^{1}+\ldots+\alpha_{3} u_{i}^{3}+Z_{i} \beta+\varepsilon_{i}
$$

where $u_{i}^{1}, u_{i}^{2}$ and $u_{i}^{3}$ are dummy variables for the levels of sophistication of use?

The relationship between the specific writing, math and computer tasks and wages might result from the skills needed to perform these tasks, but are likely to reflect unobserved heterogeneity associated with these tasks as well, indicating that some tasks are more common in jobs with higher earnings than others. We are however not interested in investigating the relationship between the tasks workers perform and their wages, but in the effects of skills on wages. As noted above, we have to take into account that the performance of every specific task will due to experience increase the related specific skills, even if they would not be rewarded in the labour market. To distinguish empirically between skills that really matter and skills that are obtained as a byproduct of the tasks one carries out, we regress the effects of skills on wages given the tasks of a worker:

$$
\ln W_{i}=C+\alpha_{1} u_{i}^{1}+\ldots+\alpha_{3} u_{i}^{3}+\gamma_{1} s_{i}^{1}+\ldots+\gamma_{3} s_{i}^{3}+Z_{i} \beta+\varepsilon_{i}
$$

\footnotetext{
${ }^{7}$ For computer use the data distinguish four different levels of sophistication. Hence, for computer use $u_{i}^{4}$ is added to equation (7).
} 
where $s_{i}{ }^{1}, s_{i}{ }^{2}$ and $s_{i}{ }^{3}$ equal the skill levels for workers who apply writing, math and computers at the different levels of sophistication. $s_{i}{ }^{1}, s_{i}{ }^{2}$ and $s_{i}{ }^{3}$ equal 0 if this level of sophistication does not apply to the worker's job. Now, the parameters $\gamma_{1}, \gamma_{2}$ and $\gamma_{3}$ represent the effects of increased skills, conditional on the level of sophistication at which writing, math or computers are being used. ${ }^{8}$

\section{Estimation results}

\subsection{Writing skills}

Table 2 presents the estimation results of equations (6)-(8) for writing. The estimates reported in the first column of Table 2 show that there is a large difference in the average wages of workers who write at work and workers who do not write (the computer use dummy in equation (6) is naturally replaced by a dummy variable for pen use). People who write at work, regardless of the level of sophistication of writing, earn on average 56.4 percent $(\exp (.447)-1)$ higher wages than workers who do not have to write. The results in column 2 show that about half of this difference can be explained by education, experience, part-time work, gender, being married and the cross-dummy gender $\times$ married.

To find out why pen use yields higher wages, it is important to understand what tasks workers perform using a pen. The results shown in column 3 are the regression coefficients from estimating equation (7) and distinguish between (i) filling in forms, notices or signs, (ii) writing short documents (for example, short reports, letters or memos), and (iii) writing long

\footnotetext{
${ }^{8}$ For computer use the data distinguish four different levels of sophistication. Hence, for the analysis of the returns to computer skills $s_{i}^{4}$ and $u_{i}^{4}$ are added to equation (8).
} 
documents with correct spelling and grammar (for example, long reports, manuals, articles or books). It turns out that workers who fill in forms do not significantly earn more than people who do not have to write at work. Only workers who write short or long documents obtain significantly higher earnings, with the coefficient for writing long documents being twice the coefficient for writing short documents.

The next question is whether these wage differentials reveal labour-market returns for the skills needed to perform these tasks, rather than some unobserved differences in the requirements and tasks that are relevant in different jobs. Adding the skills variables to the regression equation (equation (8)) shows the effect of writing skills on wages, keeping the level of sophistication of writing constant. The regression results are shown in column 4 of Table 2. The regression results show that both the skills to write long and short documents have a significant and positive effect on wages. A 1 point increase on the skill scale (which varies from 0 to 4 ; see Table 1) adds 3-4 percent to the worker's wage. The difference between both skills is not statistically significant, however. These regression results for writing skills suggest that there are no large differences in the skills to write long or short documents. The effect of the ability to fill in forms is not significantly different form zero. ${ }^{9}$

\section{INSERT TABLE 2 OVER HERE}

\subsection{Math skills}

Table 3 reports the results from an identical regression analysis for the use of math at work. Similar to the workers who write at work, using some form of math - which has been

\footnotetext{
${ }^{9}$ Including additional control variables to the regression equation, such as industry and occupational dummies and other labour-market variables such as tenure, temporary jobs etc. does not lead to different conclusions.
} 
measured by a dummy variable for math use in equation (6) - yields substantially higher wages (43.0 percent). This difference decreases to 17.4 percent when some standard labourmarket control variables are added to the regression equation. Distinguishing between the three different levels of sophistication of math shows that only people who use math for doing calculations or for advanced mathematical procedures, earn significantly more than others (column 3). So again there seems to be a heterogeneity bias when treating the context of "math use" equally for all workers. The regression results reported in the final column of Table 3 show that there are no labour-market returns for the most straightforward math skills such as adding and subtracting when keeping the level of sophistication of use constant. In addition, there are no returns to skills for calculations using decimals, percentages or fractions. This implies that although the use of this form of math seems to be typical for better paid workers, the skill in itself is not scarce and not rewarded. Only the ability to apply advanced mathematical procedures has a significant labour-market return of some 2.5 percent for a 1 point increase on the skills scale, which is somewhat lower than the returns to writing skills reported in the last column of Table 2.

This regression analysis of math use and skills on wages reveals that not every type of math use is associated with the same increase in average wages. Furthermore, even if for a certain type of math use wages are higher than average, this does not imply that the skills needed to carry out this task effectively explain wage differentials between workers. For most mathematical applications there seems to be a coincidental correlation (unobserved heterogeneity) between the group of workers who uses such mathematical applications (and for whom this is important) and their wages. Only for advanced mathematical procedures there seems to be a significant effect of skills on wages.

\section{INSERT TABLE 3 OVER HERE}




\subsection{Computer skills}

The final set of regressions is reported in Table 4 and shows the effects of computer use and computer skills on wages. The first column of Table 4 reports a wage differential between computer users and non-users of 57.6 percent. About half of this wage differential can be explained by the standard labour-market variables (column 2).

In column 3 the results of estimating equation (7) are reported. Here the level of sophistication of computer use is positively correlated with the labour-market returns. However, when we include computer skills, no significant positive effects are found. ${ }^{10}$ These estimates suggest that computer skills are not important in explaining the wage differentials between computer users and non-users and that these wage differentials are in all likelihood caused by other factors. Only the point estimate for the computer skills at the highest level of sophistication of computer use is positive, and the level of significance comes close to 10 percent, indicating that increases in computer skills might have a substantial effect on the wages of computer programmers and related occupations using computers at the advanced level. ${ }^{11}$

\section{INSERT TABLE 4 OVER HERE}

\section{Interpretation and discussion}

\footnotetext{
${ }^{10}$ We also investigated equations including information about tenure, whether the job a worker occupies is temporary or permanent, the number of hours worked and the number of hours worked squared. Although all estimates on these variables are significant at the 5 percent level, they do not change the overall picture shown in Table 4. We have also ran regressions for men and women separately. Again the magnitude of the results does not change significantly. The results of taking into account the importance, level of sophistication and effectiveness of computer use (as shown in the other columns of Table 4) are also comparable if we include additional variables and run separate regressions for male and female workers.

11 The fact that the coefficient is not significant at the 5 percent level might also be due to the rather small number of people in the sample using the computer at the advanced level ( $n=126$, e.g. Table 1).
} 
The main goal of this study has been to investigate the labour-market returns to math, writing and computer skills using unique and detailed information on the importance in the job, and the level of sophistication and effectiveness of these tasks at work. The results from the empirical analysis presented in this paper confirm previous findings that computer users earn higher wages than non-users but adds to this that the effectiveness of computer use, used to approximate computer skills, does not yield labour-market returns, whereas the ability to write and carry out mathematical procedures does yield labour-market returns.

Since Krueger (1993) showed that computer users earn substantially higher wages than non-users, a great many authors have argued that specific skills are required to be able to increase productivity using a computer. Krueger argued that computer skills are very important to occupy a job, while others argued in favour of the relevance of skills complementing computers. In this respect, Murnane and Levy (1992) have argued that besides hard skills (such as mathematics and writing) and soft skills (such as the ability to work in groups), the skills to use computer equipment to carry out tasks are the basic skills every employee should embody. DiNardo and Pischke (1997) have shown that not only computer use but also workers using pens receive higher wages. On the basis of this result they concluded that not computer skills but a more general set of unobserved skills should be responsible for the computer wage premium.

Our regression results suggest that although the effect of pen use on wages cannot be denied, the comparison between the pen wage premium and the computer wage premium does not seem to be justified. ${ }^{12}$ On the one hand, we find that computer skills do not seem to

\footnotetext{
${ }^{12}$ The results suggest that there is a substantial effect of writing skills on wages. The finding of DiNardo and Pischke (1997) that people who use a pen earn more than average, can therefore be understood as a return to these writing skills. Of course, not every workers who uses a pen will earn more, but within the group of penusers there is a large fraction of people who have to write short or long documents and whose skills to do so are rewarded in the labour market. Trivial skills involving a pen have no returns.
} 
determine earnings. On the other hand, our results suggest that the pen wage premium depends to a large extent on the way in which a pen is used. Writing short or long documents is likely to lead to higher wages, while filling in forms is unlikely to yield any returns. Based on actual skill measures we show that, in contrast to computer skills, writing skills and math skills (the other basic skill) seem to be able to explain wage differentials between workers.

Our overall reading of the regression results presented in this paper is the following. First, differences in computer skills between workers are unlikely to explain why workers using a computer earn higher wages than non-users. There are only returns to computer skills if the computer is used in an advanced manner. This suggests that for most jobs - although the computer might contribute substantially to productivity - the tasks to operate the computer are not of central importance. In most instances operating the computer is a routine job activity, which is not particularly the employer's motivation for hiring a worker and, as a result, the worker is not paid for the performance of these activities. ${ }^{13}$ These results also lead to the conclusion that large investments in computer skills and intensive educational programs to teach pupils how to use computers are unlikely to be effective. Computer skills are therefore unlikely to become a basic skill, such as writing and math.

\section{References}

Ashton, D., Davies, B., Felstead, A., and Green, F., 1999. Work skills in Britain. ESRC Centre on Skills Knowledge and Organisational Performance.

Bell, B.D., 1996. Skill-biased technical change and wages: evidence from a longitudinal data set. Working paper, Nuffield College, October.

\footnotetext{
${ }^{13}$ The reason why computer users earn higher wages than non-users has not been answered in this paper and is beyond the scope of the current analysis. There is however evidence that high-wage firms (controlling for demographic and firm factors) adopt computers first (e.g., Chennells and Van Reenen, 1997 and Doms, Dunne and Troske, 1997). Using individual worker data, and instrumental variables for wages, Borghans and Ter Weel (2001) show that it is most likely that the level of individual wages determines computer use, and that individual computer use does not substantially increase wages. This latter result is consistent with estimates presented by Enforf and Kramarz (1997) and Entorf et al. (1999) for France.
} 
Borghans, L. and Ter Weel, B., 2001. Computers, skills and wages. Working paper, Maastricht University, May.

Borghans, L. and Ter Weel, B., 2002. Do older workers have more trouble using a computer than younger workers? In: Polachek, S. (Ed.), Research in Labor Economics, pp. 139173.

Chennells, L. and Van Reenen, J., 1997. Technical change and earnings in British establishments. Economica 64, 587-604.

DiNardo, J.E. and Pischke, J.-S., 1996. The return to computer use revisited: have pencils changed the wage structure too? NBER Working Paper 5606, June.

DiNardo, J.E. and Pischke, J.-S., 1997. The return to computer use revisited: have pencils changed the wage structure too? Quarterly Journal of Economics 112, 291-303.

Doms, M., Dunne, T. and Troske, K.R., 1997. Workers, wages and technology. Quarterly Journal of Economics 112, 253-290.

Entorf, H., Gollac, M. and Kramarz, F., 1999. New technologies, wages, and worker selection. Journal of Labor Economics 17, 464-491.

Entorf, H. and Kramarz, F., 1997. Does unmeasured ability explain the higher wages of new technology workers? European Economic Review 41, 1489-1509.

Hamilton, B., 1997. Returns to computer skills and black-white wage differentials. Working paper, John M. Olin School of Business, March.

Krueger, A.B., 1993. How computers have changed the wage structure: evidence from microdata, 1984-1989. Quarterly Journal of Economics 108, 33-60.

Murnane, R.J. and Levy, F., 1992. Teaching the new basic skills, Principles for educating children to thrive in a changing economy. Free pres, New York.

OECD, 2000. Adult literacy and life skills: computer literacy. OECD, Paris.

Spenner, K.I., 1990. Skill: meaning, methods and measures. Work and Occupations 17, 399421. 
Table 1

Descriptive statistics

\begin{tabular}{|c|c|c|c|}
\hline & mean & $\begin{array}{c}\text { standard } \\
\text { deviation }\end{array}$ & $\begin{array}{c}\text { number of } \\
\text { observations }\end{array}$ \\
\hline Pen use & .861 & .346 & 2,467 \\
\hline Math use & .823 & .382 & 2,467 \\
\hline Computer use & .692 & .462 & 2,467 \\
\hline Writing skills (0-4) & & & 2,123 \\
\hline filling in forms & 3.095 & 1.111 & 185 \\
\hline short documents & 2.823 & 1.325 & 362 \\
\hline long documents & 2.026 & 1.617 & 1,576 \\
\hline Math skills (0-4) & & & 2,031 \\
\hline adding, subtracting & 3.307 & 1.019 & 297 \\
\hline calculations & 2.670 & 1.542 & 490 \\
\hline advanced math & 1.607 & 1.619 & 1,244 \\
\hline Computer skills (0-4) & & & 1,707 \\
\hline simple & 2.460 & 1.356 & 637 \\
\hline moderate & 3.149 & .867 & 645 \\
\hline complex & 3.455 & .751 & 299 \\
\hline advanced & 3.821 & .415 & 126 \\
\hline Other variables & & & 2,467 \\
\hline hourly wage (£) & 7.427 & 9.253 & \\
\hline educational level (0-5) & 2.226 & 1.533 & \\
\hline experience (years) & 19.192 & 10.786 & \\
\hline part-time job (0-1) & .253 & .435 & \\
\hline female $(0-1)$ & .471 & .499 & \\
\hline married $(0-1)$ & .693 & .461 & \\
\hline
\end{tabular}

Note: The data are taken from the Skills Survey of the Employed British Workforce. The number of observations for writing, math and computer skills are derived in such a way that they report the highest level at which the effectiveness can be assessed. The educational levels are defined according to the British classification from low to high (No diploma (0) to University (5) see text for more details). 
Table 2

OLS regressions for the effect of writing and writing skills on pay (dependent variable: log hourly wage (standard errors in parentheses))

\begin{tabular}{|c|c|c|c|c|}
\hline & 1 & 2 & 3 & 4 \\
\hline pen use & $.447(.033)^{*}$ & $.235(.031)^{*}$ & & \\
\hline filling in forms $\left(u^{1}\right)$ & & & $.049(.045)$ & $.105(.054)$ \\
\hline short documents $\left(u^{2}\right)$ & & & $.150(038)^{*}$ & $.100(.053)$ \\
\hline long documents $\left(u^{3}\right)$ & & & $.300(.032)^{*}$ & $.169(.051)^{*}$ \\
\hline \multicolumn{5}{|l|}{ Skills } \\
\hline filling in forms $\left(s^{1}\right)$ & & & & $-.020(.011)$ \\
\hline short documents $\left(s^{2}\right)$ & & & & $.039(.013)^{*}$ \\
\hline long documents $\left(s^{3}\right)$ & & & & $.031(.011)^{*}$ \\
\hline \multicolumn{5}{|l|}{ Education } \\
\hline NVQ 1 & & $.090(.042)^{*}$ & $.083(.042)^{*}$ & $.073(.042)$ \\
\hline NVQ 2 & & $.245(.030)^{*}$ & $.221(.030)^{*}$ & $.199(.030)^{*}$ \\
\hline NVQ 3 & & $.307(.036)^{*}$ & $.280(.035)^{*}$ & $.252(.036)^{*}$ \\
\hline NVQ 4 & & $.549(.038)^{*}$ & $.497(.039)^{*}$ & $.456(.039)^{*}$ \\
\hline University & & $.741(.041)^{*}$ & $.684(.042)^{*}$ & $.631(.043)^{*}$ \\
\hline \multicolumn{5}{|l|}{ Other controls } \\
\hline experience & & $.021(.002)^{*}$ & $.019(.002)^{*}$ & $.019(.002)^{*}$ \\
\hline experience squared & & $-.030(.005)^{*}$ & $-.027(.005)^{*}$ & $-.027(.005)^{*}$ \\
\hline part-time & & $-.123(.027)^{*}$ & $-.099(.027)^{*}$ & $-.090(.027)^{*}$ \\
\hline female & & $-.155(.037)^{*}$ & $-.166(.037)^{*}$ & $-.175(.037)^{*}$ \\
\hline married & & $.058(.032)$ & $.053(.031)$ & $.054(.031)$ \\
\hline female $\times$ married & & $-.033(.045)$ & $-.031(.044)$ & $-.029(.044)$ \\
\hline constant & $1.441(.031)^{*}$ & $1.173(.048)^{*}$ & $1.198(.048)^{*}$ & $1.219(.048)^{*}$ \\
\hline Adjusted $\mathrm{R}^{2}$ & .076 & .295 & .313 & .321 \\
\hline
\end{tabular}

Note: The data are taken from the Skills Survey of the Employed British Workforce. * = significant at the 5 percent level. All estimates are OLS. The educational levels are defined according to the British classification from low to high (NVQ 1 to University) and no educational degree is taken as the reference group. 
Table 3

OLS regressions for the effect of math use and math skills on pay (dependent variable: log hourly wage (standard errors in parentheses))

\begin{tabular}{|c|c|c|c|c|}
\hline & 1 & 2 & 3 & 4 \\
\hline math use & $.358(.030)^{*}$ & $.160(.028)^{*}$ & & \\
\hline adding, subtracting $\left(u^{1}\right)$ & & & $.016(.038)$ & $.059(.055)$ \\
\hline calculations $\left(u^{2}\right)$ & & & $.175(.034)^{*}$ & $.219(.055)^{*}$ \\
\hline advanced math $\left(u^{3}\right)$ & & & $.207(.030)^{*}$ & $.186(.051)^{*}$ \\
\hline \multicolumn{5}{|l|}{ Skills } \\
\hline adding, subtracting $\left(s^{1}\right)$ & & & & $-.014(.013)$ \\
\hline calculations $\left(s^{2}\right)$ & & & & $.002(.013)$ \\
\hline advanced math $\left(s^{3}\right)$ & & & & $.025(.012)^{*}$ \\
\hline \multicolumn{5}{|l|}{ Education } \\
\hline NVQ 1 & & $.102(.042)^{*}$ & $.096(.042)^{*}$ & $.094(.042)^{*}$ \\
\hline NVQ 2 & & $.254(.030)^{*}$ & $.234(.030)^{*}$ & $.234(.030)^{*}$ \\
\hline NVQ 3 & & $.314(.036)^{*}$ & $.297(.036)^{*}$ & $.295(.036)^{*}$ \\
\hline NVQ 4 & & $.568(.038)^{*}$ & $.537(.039)^{*}$ & $.535(.039)^{*}$ \\
\hline University & & $.759(.042)^{*}$ & $.724(.042)^{*}$ & $.721(.042)^{*}$ \\
\hline \multicolumn{5}{|l|}{ Other controls } \\
\hline experience & & $.020(.002)^{*}$ & $.021(.002)^{*}$ & $.020(.002)^{*}$ \\
\hline experience squared & & $-.029(.005)^{*}$ & $-.028(.005)^{*}$ & $-.028(.005)^{*}$ \\
\hline part-time & & $-.125(.027)^{*}$ & $-.111(.027)^{*}$ & $.111(.027)^{*}$ \\
\hline female & & $-.142(.037)^{*}$ & $-.140(.037)^{*}$ & $-.141(.037)^{*}$ \\
\hline married & & $.067(.055)$ & $-.056(.032)$ & $.055(.032)$ \\
\hline female $\times$ married & & $-.050(.045)$ & $-.043(.044)$ & $-.041(.044)$ \\
\hline constant & $1.533(.027)^{*}$ & $1.227(.048)^{*}$ & $1.243(.047)^{*}$ & $1.242(.048)^{*}$ \\
\hline Adjusted $\mathrm{R}^{2}$ & .061 & .287 & .298 & .299 \\
\hline
\end{tabular}

Note: See Table 2 for details. 
Table 4

OLS regressions for the effect of computer use and computer skills on pay (dependent variable: log hourly wage (standard errors in parentheses))

\begin{tabular}{|c|c|c|c|c|}
\hline & 1 & 2 & 3 & 4 \\
\hline computer use & $.455(.024)^{*}$ & $.288(.024)^{*}$ & & \\
\hline simple $\left(u^{1}\right)$ & & & $.179(.027)^{*}$ & $.211(.044)^{*}$ \\
\hline moderate $\left(u^{2}\right)$ & & & $.347(.028)^{*}$ & $.472(.077)^{*}$ \\
\hline complex $\left(u^{3}\right)$ & & & $.406(.036)^{*}$ & $.554(.130)^{*}$ \\
\hline advanced $\left(u^{4}\right)$ & & & $.491(.058)^{*}$ & $-.204(.470)$ \\
\hline \multicolumn{5}{|l|}{ Skills } \\
\hline simple $\left(s^{1}\right)$ & & & & $-.013(.014)$ \\
\hline moderate $\left(s^{2}\right)$ & & & & $-.039(.023)$ \\
\hline complex $\left(s^{3}\right)$ & & & & $-.043(.036)$ \\
\hline advanced $\left(s^{4}\right)$ & & & & $.183(.123)$ \\
\hline \multicolumn{5}{|l|}{ Education } \\
\hline NVQ 1 & & $.073(.041)$ & $.069(.041)$ & $.071(.041)$ \\
\hline NVQ 2 & & $.200(.030)^{*}$ & $.179(.030)^{*}$ & $.178(.030)^{*}$ \\
\hline NVQ 3 & & $.248(.035)^{*}$ & $.214(.035)^{*}$ & $.212(.035)^{*}$ \\
\hline NVQ 4 & & $.476(.038)^{*}$ & $.431(.038)^{*}$ & $.426(.038)^{*}$ \\
\hline University & & $.646(.042)^{*}$ & $.566(.043)^{*}$ & $.559(.043)^{*}$ \\
\hline \multicolumn{5}{|l|}{ Other controls } \\
\hline experience & & $.020(.002)^{*}$ & $.021(.002)^{*}$ & $.020(.002)^{*}$ \\
\hline experience squared & & $-.029(.005)^{*}$ & $-.030(.005)^{*}$ & $-.030(.005)^{*}$ \\
\hline part-time & & $-.085(.027)^{*}$ & $-.065(.027)^{*}$ & $-.068(.027)^{*}$ \\
\hline female & & $-.188(.036)^{*}$ & $-.188(.036)^{*}$ & $-.186(.036)^{*}$ \\
\hline married & & $.061(.031)$ & $.067(.031)^{*}$ & $-.065(.031)^{*}$ \\
\hline female $\times$ married & & $-.036(.044)$ & $-.034(.043)$ & $-.032(.043)$ \\
\hline constant & $1.511(.020)^{*}$ & $1.236(.044)^{*}$ & $1.235(.043)^{*}$ & $1.240(.043)^{*}$ \\
\hline Adjusted $\mathrm{R}^{2}$ & .139 & .322 & .336 & .343 \\
\hline
\end{tabular}

Note: See Table 2 for details. 